\title{
The identity of destruction and the construction of identity in L'amour la fantasia of Assia Djebar and Une odeur de mantèque of Mohammed Khair-Eddine
}

\author{
Hicham Jirari ${ }^{1}$, Karima Salah-Eddine (Translator) \\ ${ }^{1}$ University of Hassan II (Morocco), Faculty of Science and Technology-Mohammedia \\ ${ }^{2}$ University of Mohammed V (Morocco), Faculty of Sciences-Rabat
}

\begin{abstract}
Francophone diaspora literature reveals unstable worlds. In facts, the metamorphosis of the self would be a reflection of a number of unconventional narrative forms: reflexive territories whose benchmarks would be, mainly, at the level of migratory movements. Such a broad subject could be partially identified on the basis of a definite corpus. Two authors draw attention to this: Assia Djebar and Mohammed Khaïr-Eddine. Their respective works, L'Amour la fantasia and Une Odeur de mantèque, lead the recipient to a rather intriguing journey insofar as memory, enunciation and temporality intersect with the fields of otherness and de-territoriality. By means of a comparative approach, we propose a modest illumination on these inner-self and outer-self problematized spaces. Weighing with all their strenght on postmodernity, they still resonate in the $21^{\text {st }}$ century with the critical margins of the collective unconscious.
\end{abstract}

Keywords - francophone diaspora, literature, narrative forms, otherness, de-territoriality.

Francophone diaspora literature unveils unstable worlds in which writers freely express their sensibility. In fact, metamorphosis of the self would be in the image of unconventional narrative forms : reflective territories whose benchmarks would be located, mainly, at the level of the migratory movements. Assia Djebar and Mohammed Khair-Eddine are two authors who draw attention to this. The first is the dean of Algerian literature of French language. Having accompanied generations of writers, in 1985 she wrote L'Amour, la Fantasia, "a narrative that covers the crucial moments during the French occupation ... to the war of liberation" (Chikhi 28). The second author is one of the great figures of Moroccan francophone literature, in 1976 he published Une Odeur de mantèque where "dream is synonymous to wandering, long descent into hell and quest for lost paradise" (Yelles 26). Their respective works take the reader to a rather intriguing journey insofar as memory, enunciation and temporality intersect.

Our study proposes, using a comparative approach, to bring an enlightenment to the problem of diversity as a determining factor in the destruction / construction process. We shall first examine the geo-cultural exile by considering the question of Deterritorialization. Next, we will discuss the dehumanization of the subject: this theme would retrace lost points of reference, at times linguistic, at times existential. Finally, we will look at the phenomenon of inter-migration. As the prefix refers to a reciprocal action, mobility as suggested by migration refers to a back and forth phenomenon involving selfdisplacement and displacement.

\section{GEO-CULTURAL EXILE}

The notion of deterritorialisation goes to the Deleuzian philosophy. It refers to a process inherent in the "passage through the concept for the philosopher or through the artistic creation for the artist" (Ginoux 104). Throughout the novel, A. Djebar and M. Khairr-Eddine call for the notion of deterritorialisation. Isolated as a terminology (multi) disciplinary, it can be identified, in literature, as an ideological representation specific to the writings on difference. For, "Francophone writers ... have expressed their sense of strangeness in the [French] language, a language they have owned and tamed in a thousand ways" (Gauvin 11). Une odeur de mantèque opens intriguing breaches in the sense that the narrative manifests itself between two adjacent shores: paradise and hell. This narrative is an introduction to the revolutionary story of an old man struggling with a magic mirror he formerly stole from a dealer that he killed. This old man has become like an undead, plunged in a delirium of consciousness or unconsciousness, designated by a pejorative qualifier "old scoundrel" in a heavy adventure articulated around a dynamic instance, a sorcerer called 
"super old." The resulting escapade betrays an overlap between thoughts and backgrounds, between a referential hell and an incredibly tempting paradise:

"... Old murderer, you really deserve that I make you know paradise and hell. Paradise is only one of the dreary aspects of your intelligence. Hell is what is best in you that you have fled since a long time. Therefore, I am going to take you there. "... The super old dragged him ..." (Khaï-Eddine 24-25)

As much as the register of darkness is heartbreaking as much as the desire for the Authentic, that is the desire for a magical transport, reveals the removal of the individual identity. The phantasmagoric mode, via which this experience is associated, constitutes, then, a phase of assessment to externalize far from the local and from its load. The externalization of the verb is an important phase that also engages the narrator Assia Djebar. Thanks to her father's teachings, she learned the French language and used it to escape the exiguity of the mother tongue. This linguistic nomadism is only a subjective manifestation of cultural dis-territoriality. It thus reflects the complex projection of the female character in an in-between where the expression of externalized individuality borrows a foreign syntactic coding : "Only to say that I exist and my heart throbs. To write is not it to tell "me"?" (Djebar 87)

Hence, the geo-cultural territory becomes a hell worth being deserted. Its denunciation by assertiveness leads the narrator to create her own circle of belonging; words. More than that, she has joined by this inner uprising what Abdelkebir Khatibi considers a bilingualism internal to every language : "(this one) operates a separation ... according to a movement that never ceases to double and to split itself. The French language is not the French language, it is more or less, all the internal and external languages that make it and defeat it." (Khatibi 188)

The voluntary exile of verbalized thought underlines the role of the emotional deficiency caused by the incapacity to translate feelings using the mother tongue in the understanding of the attachment to the Other. The man could dare to mark this deep sensitivity towards his correspondent, as it is the case, in the novel, for the father figure. By indicating the mother (of the narrator) by her name in his mail, he breaks the rule of his indigenous congeners. He did it in French. An error to avoid or an example to follow? The narrator follows the vicarious cadence by assuming: "the fever which presses me hinders in this desert of expression. My voice which looks for itself quests the orality of a sensitivity that is late." (Djebar 72) Is it a rebirth of oneself by the liberation of the verb? Is it a cry of distress incriminating a tradition of orality devoted to the reproduction of the forbidden? Is it a hint to this imaginary that preserves the reinvention of the literary text by the covert speech, the right to "opacity" (Crowley 106) ?

\section{II. \\ THE DEHUMANIZATION OF THE SUBJECT}

2.1 The linguistic identification

Access to the discourse is both providential and problematic in the environment of Chérifa, one of the female characters embodied in L'Amour la fantasia. The father of a family who decides to dare putting his wife's name on the postcard, upsets the pre-established relationship scheme in the tribal/patriarchal system. In fact, by moving from a simple family member to the nominated wife, the mother reaches the status of a partner. This approach propels Tahar's social circle (the father) into another reality : that of the conjugal family. On the other hand, the mother's internalization of the relational effect prevents her from living harmoniously her humanity "It was, in fact, the most audacious of manifestations of love. Her modesty suffered at this very moment. Hardly if she argued with him (the father), though, her vanity of wife, secretly flattered." (Djebar 58)

Access to the emotional dimension through the discovery of sensuality encloses a real tragedy. What the female figure perceives as a sublimation of the feeling of love is perceived by the autochthonous male figure as the experience of defloration. The human sexuality, being above all linguistic, is reflected in the mirror of the conjugal institution into two fractions: the first one is that of prayers supposed to precede penetration, the second is that of the conjugal rape.

"The young man had always known that when he would cross the threshold of the room -a conch of transcendental love- he would feel himself seized with a silent gravity, and before turning to the immobile virgin, he should indulge himself in religious prayers (...)" (Djebar 152154)

The gateway overlooking the liberation and selffulfillment does not open since the ancestral tradition inhibits the relational exchange (verbal / behavioral) which stumbles over the idiomatic ramparts of the French language. The appropriation of this language is not less dramatized by Khaï-Eddine. At first sight, the text puts in perspective certain aspects of the vernacular language. The wandering lived by the old traveler condemns the writing to a plasticity whose main vector is the spoken; 
sometime encrusted in literal translation "ah yes, the dog, yes, yes, I am only a dog and you, Master, my crusher, yes, yes, it is you who has crushed me for a long time, forever " (Khaï-Eddine 23), sometimes sabotaging narrator's credibility by a disconcerting orality :

"But, in fact, I hardly ever think of my family. What happened to that old carrion? What is it now? As said a good philosopher. Here is a German as usual. Would not that be Nietzsche? Yes that's it. Hold on, I am multiplying, who am I, exactly? Perhaps not the one you believe me to be?" (Khaïr-Eddine 145)

Simple linguistic intimidation or latent manifestation of an existential crisis?

\subsection{Existential spotting}

Reconstituted in bits, the burdensome past unfolds its temporal ends. Since his childhood, the protagonist is presented as a "sick" being against whom the "evil eye" weighs: " he (the child) will dream that he is in hell without ever loosing sight of the real world » (KhairEddine 28) the fear of an evil, that has probably never been proved seems to have predisposed the old man to live a life of defiance, bravado. Without any concern for the end of life at the moment of death, the narrator, through the voices that inhabit him, endorses a practically stoic vision of transcendence. Indeed, the idea of transcendence presupposes the absence of a link between two discontinuous elements: life and death. These two parallels, both visualized by the «hero», have been approached through a transitory abyss « the super-old tapped on the shoulder of the old man and said: "Let's go!" I lead you where no man has ever been. No, not to hell, nor to heaven, but into a different texture. » (KhaïrEddine 35-36)

When he deigns to acknowledge his ethnic heritage, the recognition of his condition as a Berber, a dirty Chleuh, is mingled with a late heroism deeply rooted in the collective curse :

"Sometimes we fell because we thought we were weak, because we doubted ourselves. Every time, we had to show the assaulting forces that we were determined to obey only that thin, floating thread which was moving somewhere in us like the sparkling of stars" (KhairEddine 170)

Writing is a sparkle of stars in the relationship between the author and the reader, Khair-Eddine's novel, a possible romantic replica of what Georges Mottier regards as aesthetic in human experience: "For the ideal
Aesthetics is fully realized whenever art represents, in accordance with the degree of development of the spirit from which it originates and to which it is addressed, what Man experiences in contact with life and things." (233)

The correspondence with l'Amour, la fantasia, reaches the tragic dimension of destiny correlated with the idea of reverence. Rather a tripolar reverence: that of the writer, the narrator and the I first person. The first instance revisits the History of Algeria, its own, and instructs the second instance to explore the depths of individuality :

"As far as I am concerned, while I inscribe the most banal of sentences, immediately the ancient war between two nations crisscrosses its signs deep in my writing. This one... goes from the images of war to the formulation of a contradictory, equivocal love ... The autobiography practiced in the adverse language is woven as fiction, at least as long as the forgetting of the dead carried out by writing does not effectuate its anesthesia. Believing "to go through me", I do only choose another veil." (Djebar 301-302)

Thus, between monologue and dialogue, Assia Djebar fragments her humanity in such a way as to rediscover a source of individual and collective well-being, which is difficult to maintain in the expression of love and violence; similarly Mohammed Khaïr-Eddine looks for himself in memories and hallucinations moved by the desire to recover a herois $m$ that escapes his old persona.

\section{INTER-MIGRATION}

3.1 Movement within the self

The title of this third part emphasizes the reciprocal relation between the subject and the object of its conquest. The latter is primarily internal. In the Moroccan novel, the readership would plunge into the meanders of a personality affected by delirium, hallucination, or even mortification. This journey to the depths of humanity introduces the relation to another, unknown this time in the sense that it takes on more than an appearance, invested in a metaphorical language :

He bent his biceps, tried again to lift the burden that crushed him, in vain. "It is a demon that strikes me," he said to himself, "a big demon, a swelling." They told me in bled similar stories.... Others say that the demon sodomizes you as you sleep. The old man felt his anus, then he put his finger to his nose. It's all wet, Good Lord! This idiot fucked me. (Khair-Eddine 30)

The mode in absentia dominates in this language since the metaphorical element leaves room for the metaphorizing 
one; to note that the narrator could have used Satan or the Djinn (singular of djnoun signifying spirit or genius) as substitute. In any case, the idea of impotence vis-a-vis this Other, the unknown referent, transforms the interiority of the old man into arranged spaces. In other words, the understanding of this strange crush requires access to a zone of recollection that would incontestably lead to childhood :

"Re-becoming child, $\mathrm{Pa}$ and I were waiting for the bus to go to school ... As the bus was late... we decided to go straight in the opposite direction so as not to be late for the exam... My father evaporated along the way, me remaining there, alone, in the building. Being there for a long time, running, each time mistaking the doors... and it was then that a red dog came out of the end of a hall and came to take me by the right arm, dragging me without barking, saying absolutely nothing as long as I had not manifested/showed my will ...

Me: I came for the exam.

The Dog: (He laughs or rather smiles without showing his teeth.) It will not take place until next week. We got you." (Khair-Eddine 60-61)

Always the same process: a personified, powerful metaphorical against which clashes the innocence of a child fallen under the burden of domination. This alterity in Assia Djebar resonates differently. The construction of the narrative conceals a force of otherness manifested by a collection of perceptions. Thinking in the Algerian language and verbalizing in the French language cause a gap between what is uncommunicable/ inenarrable in the mother language and what is felt when foreign words are spoken :

"My fiction is this autobiography which is sketched out, burdened by the inheritance that encumbrances me. Am I going to succumb? But the tribal legend zigzag in the passages and it is in the silence of the words of love, never spoken, of the unwritten mother tongue, transported like a chattering of an unknown and haggard mime, it's in that night that imagination, begging of the streets, crouched..." (Djebar 304)

Many times, this dominance relationship is discerned through various experiences including that of love and manifestation of desire. It is indeed the dominance of a language, made hers (by the narrator), but also the domination of the latter by a disorder of expression which hampers the transposition of the affective reality (noting hereinafter, absence of the exclamation point after Pilou darling) by a lexical field in disconformity with the tribal cultural code. The remark in public of Marie-Louise and of her fiancé (Chérifa's French neighbors) led her to the borders of a complex exoticism inspired by the perspective of the female Algerian subject: "Pilou chéri", words followed by tufts of sarcastic laughter; what to say about the destruction of what this appellation operated in me afterwards? ... Inoffensive childhood scene: an aridity of expression settles and sensitivity in its romantic period is found aphasic. (Djebar 43)

\section{3-2 Self-displacement}

The exploration of the self in contact with the other, the foreigner, is however made twice. It exposes itself primarily within the self and secondly elsewhere. What arouses curiosity, in this sense is that the withdrawal in the familiar space is motivated by a discovery of an elsewhere forbidden to the female gender. During her childhood, the narrator (the youngest of four sisters) and her elder sister discreetly crossed a forbidden territory, the library of the absent brother :

"During the same summer, the youngest sister and I were able to open the library - that of the absent brother, who had previously been locked ... In a month we read all the novels piled together ... We discovered an Album of erotic photographs and, in an envelope, postcards of Ouled-Nails full of jewelry, naked breasts." (Djebar 2021)

Self-displacement, whether placed in a context of violence (in the war against the colonizer) or under the impulse of self-determination (in relation to the cultural heritage) reveals only emptiness ("Circulating since my adolescence outside the harem, all I travel is a desert of the places "(Djebar 303)). This floating among several zones, occurring in a nonlinear temporality, indicates the concern to found a spatial filiation between a selfaccomplished individual and a parent collective self :

"In fact, I look for, a kind of milk that I would have previously been refused, plethora in love with my mother's language. Against the segregation of my heritage, the word full of love-at-the-present becomes a flight of swallows... Love, if I could write it, would reach a crucial point: here lies the risk to exhort cries, those of yesterday as those of the last century. But I only aspire to a writing of transhumance, while, as a traveler, I fill my bottles with an inexhaustible silence.” (Djebar 92-93) It is not surprising to find the same impulse of authenticity in the old protagonist of Mohammed KhaïrEddine. Straddling spaces according to his reminiscences and aspirations, the old man, like a censer of fermented butter regularly recognizes in his text, the hold of the world that he tramples over: "When he awoke, he was in a 
sky-high room, sitting on a granite bench where he seemed to be locked in." (Khair-Eddine 11)

The journeys he had made in the past, to the four corners of Morocco, biased of contracts and corruption, revived in him the vow to undertake the pilgrimage to Mecca. Sometimes pretending to have done it "God forgives me, who knows that I have made the pilgrimage to Mecca several times" (Khaï-Eddine 80), sometimes expressing the desire to go there as a final goal of absolution "I must first go to Mecca to get my sins forgiven. when? I do not know" (Khair-Eddine 102), he delights in the certainty of the "believer": abandon the zones of turmoil (dreams, illusions, memory) at the price of death, gateway to the Other, namely the world of eternal tranquility : "I will therefore try my luck or I will die here ... I will have once and for all peace that I have so desired, the sleep that has always betrayed me will not leave me anymore. "(KhaïEddine 82)

In short, our corpus traces relatively parallel paths. Their complexity, due to certain variables that require in depth analysis, is revealed through the approach of their respective spatio-cultural universes, hence the choice of a comparative approach in order to understand some main facts on Maghrebi literature in the light of the problem of otherness. The extension of these textual spaces of the seventies and eighties of the last century, in today's literary sensibilities, marks the identity crisis experienced everywhere today. But unlike socio-political actors, writers, men and women of letters, such as Mohammed Khair-Eddine and Assia Djebar, have chosen to explore the path of literature until the recipient's home by exploring, destroying, constructing by the verb the legitimacy and the right to fully exist in harmony as in paradox.

\section{REFERENCES}

[1] Al Hallaj. In Anawati, G. C. et Gardet, L. (1976). La mystique musulmane. Paris : Vrin (trad. Massignon).

[2] Arnaud, J. (2003). "Les maghrébins et le surréalisme". In Yelles, M. Habib Tengour ou l'ancre et la vague. Paris : Karthala.

[3] Chikhi, B. (2007). Assia Djebar Histoires et fantaisies. Paris : Presses de l'Université Paris-Sorbonne.

[4] Crowley, P. (2006). "Edouard Glis sant : résistance and opacité”. In Romance Studies. Vol. 24 (2).

[5] Djebar, A. (1995/1985). L'Amour, la fantasia. Paris : Albin Michel.

[6] Gauvin, L. (2007). Ecrire pour qui? L'écrivain francophone et ses publics. Paris : Karthala.

[7] Khair-Eddine, M. (2002/1976). Une Odeur de mantèque. Paris : Seuil.
[8] Khatibi, A. (1983). Maghreb pluriel. Paris: Denoël.

[9] Mottier, G. (1936). Le phénomène de L'Art. Dijon : Imp. Darantière.

[10] Ginoux, I. (1998). "Les types psychosociaux et le personnage conceptuel“. In Stengers, I., Verstraeten, P. Gilles Deleuze. Paris : Vrin. 